\title{
Pengaruh Komunikasi Terhadap Kinerja Karyawan Dengan Penempatan Kerja Sebagai Variabel Moderating Pada KSP Karya Mulya Bataan Bondowoso
}

\author{
Eko Cahyono, Toni Herlambang dan Bayu Wijayantini \\ Fakultas Ekonomi Universitas Muhammadiyah Jember \\ Email: toniherlambang@unmuhjember.ac.id dan bayu@unmuhjember.ac.id
}

\begin{abstract}
ABSTRAK
Penelitian ini bertujuan mengetahui pengaruh komunikasi terhadap kinerja karyawan dan mengetahui interaksi antara komunikasi dengan penempatan kerja karyawan KSP Karya Mulya Bondowoso. Populasi dalam penelitian ini adalah semua karyawan pada KSP Karya Mulya Bondowoso yang berjumlah 40 orang. Variabel yang digunakan yaitu sebanyak 3 variabel, yaitu variabel bebvas, variabel terikat dan variabel moderating. Alat analisis yang digunakan adalah analisis Regresi Linear Sederhana dan Moderated Regression Analysis. Hasil penelitian menunjukkan terdapat pengaruh komunikasi terhadap kinerja karyawan KSP Karya Mulya Bondowoso dengan arah positif. Hal ini membuktikan bahwa dengan adanya komunikasi yang efektif didalam penyampaian informasi akan meningkatkan kinerja. Hasil penelitian berikutnya yaitu terdapat interaksi antara komunikasi dan penempatan kerja terhadap kinerja karyawan KSP Karya Mulya Bondowoso. Hal ini berarti bahwa penempatan kerja merupakan variabel pemoderasi antara komunikasi terhadap kinerja karyawan, artinya penempatan kerja yang sesuai dengan kemampuan kerja karyawannya akan sangat mendukung efektifitas komunikasi yang dibangun dengan prinsip kepercayaan, kejujuran dan keterbukaan, hal ini tentunya akan memoderasi komunikasi sebagai informasi dalam meningkatkan efektifitas kinerja.
\end{abstract}

Kata Kunci : komunikasi, penempatan kerja, kinerja karya

\begin{abstract}
This study aims to determine the effect of communication on employee performance and find out the interaction between communication with work placements of KSP employees by Mulya Bondowoso. The population in this study were all employees at Mulya Bondowoso's KSP of 40 people. The variables used are as many as 3 variables, namely variable variables, dependent variables and moderating variables. The analysis tool used is Simple Linear Regression analysis and Moderated Regression Analysis. The results of the study showed that there was an effect of communication on the performance of KSya Karya Mulya Bondowoso's employees in a positive direction. This proves that the existence of effective communication in the delivery of information will improve performance. The results of the next study are that there is an interaction between communication and work placement on the performance of the KSP employees by Mulya Bondowoso. This means that work placement is a moderating variable between communication to employee performance, meaning that work placement that is in accordance with the work ability of its employees will greatly support the effectiveness of communication built on the principles of trust, honesty and openness, this will certainly moderate communication as information in increasing effectiveness the performance.
\end{abstract}

Keywords: communication, work placement, work 


\section{PENDAHULUAN}

Sumber daya manusia didalam setiap perusahaan merupakan salah satu faktor penting dalam sebuah organisasi atau perusahaan untuk mencapai tujuan dan sasarannya melalui usaha kooperatif sekelompok orang didalamnya, sehingga dapat dikatakan sumber daya manusia adalah salah satu faktor penentu berhasil atau tidaknya suatu perusahaan dalam mencapai tujuannya. Sumber daya manusia yang dimaksud disini adalah karyawan, sehingga untuk tercapainya tujuan dari perusahaan sangat tergantung pada bagaimana karyawan dapat mengembangkan kemampuannya baik dalam mengembangkan pengetahuan, keahliannya, maupun sikapnya. Hal tersebut diperlukan supaya produktivitas kerja dari para karyawan dapat meningkat, karyawan mempunyai kecermatan dalam pelaksanaan tugas, bertumbuh suburnya kerjasama antara berbagai satuan kerja yang melaksanakan kegiatan yang berbeda. Karyawan yang mempunyai pengetahuan, keahlian, dan sikap yang baik akan bekerja secara optimal, sehingga perusahaan atau instansi dalam mengelola sumber daya manusia dapat lebih efektif dan efisien (Hasibuan, 2006).

Berhasil atau tidaknya tujuan perusahaan tentunya tidak hanya dipengaruhi oleh berapa besar dana, teknologi, maupun sarana dan prasarana yang dimiliki oleh perusahaan, tetapi terdapat hal yang paling menentukan untuk menyatukan faktor-faktor yang dimiliki oleh perusahaan, yaitu faktor sumber daya manusia, karena faktor sumberdaya manusia inilah yang menggerakkan seluruh faktor-faktor sumberdaya lainnya yang dimiliki perusahaan dalam rangka proses pencapaian tujuan perusahaan (Marwansyah, 2010).

Salah satu aspek penting dalam mengelola sumber daya manusia dalam perusahaan adalah penempatan karyawan. Penempatan karyawan merupakan serangkaian langkah kegiatan yang dilaksanakan untuk memutuskan apakah tepat atau tidaknya seorang karyawan ditempatkan pada posisi tertentu yang ada didalam perusahaan. Penempatan karyawan yang tepat merupakan cara untuk mengoptimalkan pengetahuan, keterampilan, dan sikap menuju prestasi kerja bagi karyawan itu sendiri. Hal ini sangat penting karena bagi suatu perusahaan, penempatan karyawan pada posisi yang tepat merupakan suatu hal yang utama karena erat hubungannya dengan prestasi kerja karyawan dalam memberikan manfaat yang besar bagi perusahaan. Penempatan karyawan tepat merupakan salah satu kunci untuk memperoleh hasil kerja yang optimal dari setiap karyawan, baik kreativitas dan prakarsanya akan berkembang (Hasibuan, 2006).

Selain penempatan kerja, komunikasi efektif diperlukan untuk pemeliharaan hubungan dengan para pegawai memerlukan komunikasi yang efektif. Komunikasi secara terus-menerus merupakan suatu keharusan karena melalui komunikasi berbagai hal yang menyangkut kehidupan organisasi disampaikan oleh satu pihak ke pihak yang lain. Dalam melaksanakan pekerjaan, pegawai tidak lepas dari komunikasi dengan sesama rekan sekerja, dengan atasan dan dengan bawahan. Komunikasi akan berhasil apabila pengirim pesan dan penerima pesan sama-sama mencapai pengertian dan kesimpulan yang sama sesuai dengan yang dimaksudkan, tentang apa yang sebenarnya diinformasikan. Untuk itu sangat diperlukan keterampilan dalam pemakaian bentukbentuk komunikasi dalam suatu perusahaan demi kelancaran aktivitasnya (Siagian, 2005). 
Koperasi KSP Karya Mulya Bondowoso merupakan salah satu koperasi di Kabupaten Bondowoso yang bergerak dalam bidang simpan pinjam. Koperasi KSP Karya Mulya Bondowoso memiliki 40 karyawan per Desember 2014. Seperti koperasi lain pada umumnya, Koperasi KSP Karya Mulya Bondowoso juga membutuhkan karyawan dengan kinerja yang baik sehingga dapat memberikan kontribusi yang maksimal terhadap pendapatan koperasinya, sehingga koperasi ini dapat bersaing dengan koperasi-koperasi sejenis yang ada di Kabupaten Bondowoso. Koperasi KSP Karya Mulya dalam menjalankan usahanya memiliki prosedur kerja dan proses atau kegiatan yang ada harus dilakukan dan diikuti oleh semua karyawan yang berkerja di KSP Karya Mulya Bondowoso. Berikut pada Gambar 1. adalah diagram alir sebagai model sistem komunikasi manajemen dengan penempatan kerja sebagai moderating didalam suatu aktivitas usaha ;

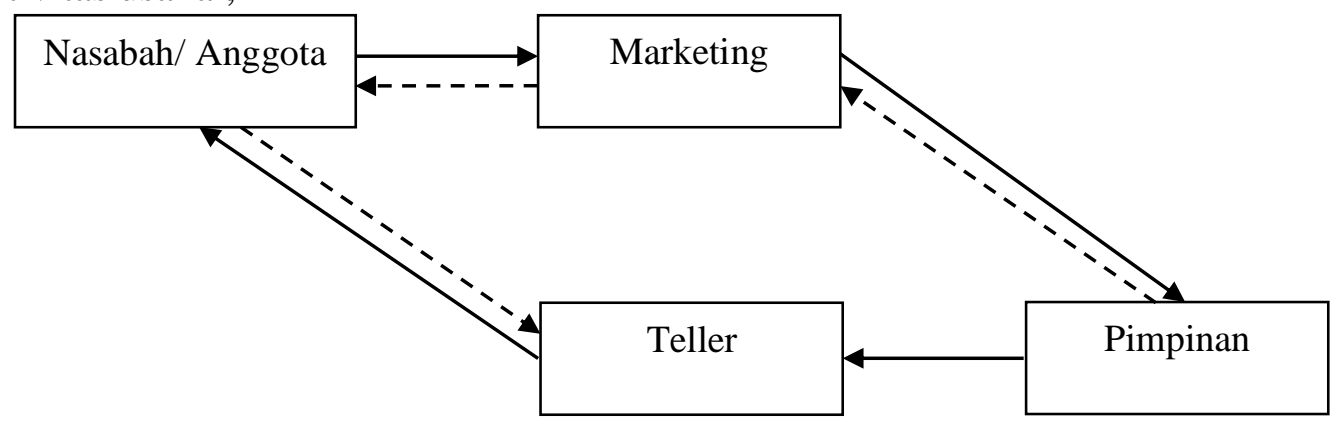

Gambar 1.1 Diagram Alir Proses Pencairan Dana Anggota Sumber: KSP Karya Mulya,2014

Berdasarkan Gambar 1., dapat diketahui bahwa sistem komunikasi yang ada di Koperasi KSP Karya Mulya, dalam hal ini masabah atau anggota koperasi dapat menghubungi pihak marketing koperasi dalam rangka melakukan proses kredit atau pihak marketing yang melakukan atau menawarkan adanya pinjaman kepada nasabah atau anggotanya. Setelah terjadi kesepakatan untuk meminjam sebuah dana kredit maka pihak marketing dapat melakukan survey atau checklist data calon nasabah, ketika data yang diterima telah sesuai atau tanpa cacat atau keraguan maka berkas pengajuan diserahkan pada pimpinan untuk mendapatkan persetujuan. Pimpinan akan memberitahukan persetujuan pada pihak marketing dan teller untuk mencairkan kredit nasabah. Nasabah atau anggota dapat langsung menemui teller dengan menyerahkan sejumlah persyaratan yang telah diinformasikan sebelumnya. Kemudahan pengaplikasian sistem komunikasi dan penempatan kerja seperti yang telah dilakukan oleh Koperasi KSP Karya Mulya, sistem ini mulai diaplikasikan pada 1 Maret 2014 dan terbukti bahwa sistem ini memberikan kemudahan bagi calon nasabah atau anggota serta sekaligus memberikan peningkatan jumlah kredit atau kreditur yang ada jumlah Debitur pada pertengahan tahun 2014 namun pada akhir tahun 2014 KSP Karya Mulya dapat mencapai 95\% dari target yang diharapkan, hal ini dapat diartikan bahwa sistem komunikasi dengan penempatan kerja sebagai moderasi telah memberikan manfaat bagi KSP Karya Mulya, kemudahan dalam proses ini dapat dirasakan oleh calon nasabah atau anggota yang memerlukan sejumlah dana kredit, calon nasabah atau anggota akan merasa gembira karena adanya kecepatan kerja karyawan didalam memproses data calon nasabah dan pencairan dana kepada nasabah yang dilakukan oleh pihak KSP Karya Mulya. 
Komunikasi merupakan salah satu kegiatan yang dilakukan untuk mengadakan hubungan dengan karyawannya. Karena itu, penting dilakukan komunikasi yang efektif agar maksud dan pesan yang disampaikan dapat diterima sesuai dengan keinginan pengirim berita. Komunikasi yang efektif adalah komunikasi yang dilakukan baik secara langsung atau melalui media dengan tujuan menimbulkan efek tertentu (Sotyandi, 2007). Nawawi (2007) menyatakan : "Pegawai harus ditempatkan dengan posisi dan perannya yang lebih jelas di dalam organisasi kerja, baik pegawai lama maupun pegawai baru yang diperoleh sebagai hasil seleksi“.Sedangkan menurut Marwansyah (2010), penempatan pegawai adalah penugasan atau penugasan kembali pegawai pada suatu pekerjaan atau jabatan baru. Kinerja yang baik adalah kinerja yang mengikuti tata cara atau prosedur sesuai standar yang telah ditetapkan, akan tetapi didalam kinerja tersebut harus memiliki beberapa kriteria agar meningkatkan produktifitas sehingga apa yang diharapkan bisa berjalan sesuai apa yang di inginkan. Meningkatkan kinerja yang baik harus introspeksi diri demi tercapainya kinerja yang lebih baik kedepannya, bekerja sesuai posisi, porsi, dan jobnya masing-masing.

Berdasarkan identifikasi masalah dapat diambil rumusan masalah yaitu apakah pengaruh komunikasi terhadap kinerja karyawan KSP Karya Mulya Bondowoso dan apakah ada interaksi antara komunikasi dan penempatan kerja karyawan terhadap kinerja karyawan KSP Karya Mulya Bondowoso. Sedangkan tujuan penelitian ini adalah untuk mengetahui pengaruh komunikasi terhadap kinerja karyawan KSP Karya Mulya Bondowoso; dan untuk membuktikan interaksi antara komunikasi dan penempatan kerja karyawan terhadap kinerja karyawan KSP Karya Mulya Bondowoso.

\section{TINJAUAN PUSTAKA}

\section{Manajemen Sumber Daya Manusia}

Manajemen Sumber Daya Manusia didalam sebuah organisasi atau perusahaan sangat penting karena Manajemen Sumber Daya Manusia merupakan perencana, pelaku, dan penentu terwujudnya tujuan organisasi. Tujuan tidak mungkin dapat terwujud tanpa peran aktif Sumber Daya Manusia meskipun alat-alat yang dimiliki oleh perusahaan sangat canggih. Alat-alat canggih yang dimiliki perusahaan tidak ada manfaatnya bagi perusahaan, jika peran aktif Sumber Daya Manusia tidak diikutsertakan. Mengatur Sumber Daya Manusia adalah sulit dan kompleks, karena mereka mempunyai pikiran, perasaan, status, keinginan, dan latar belakang yang heterogen yang dibawa ke dalam organisasi Sumber Daya Manusia tidak dapat diatur dan dikuasai sepenuhnya seperti mengatur mesin, modal, maupun gedung (Hasibuan, 2006).

\section{Komunikasi}

Komunikasi adalah suatu proses penyampaian informasi (pesan, ide, gagasan) dari satu pihak kepada pihak lain agar terjadi saling mempengaruhi diantara keduanya. Komunikasi dilakukan dengan menggunakan kata-kata (lisan) yang dapat dimengerti oleh kedua belah pihak. Apabila tidak ada bahasa verbal yang dapat dimengerti oleh keduanya, komunikasi masih dapat dilakukan dengan cara bahasa non verbal yaitu menggunakan gerak-gerik badan, menunjukkan sikap tertentu, misalnya tersenyum, menggelengkan kepala, dan mengangkat bahu (Sunarto, 2003). Komunikasi merupakan salah satu kegiatan yang dilakukan untuk mengadakan hubungan dengan karyawannya. Karena itu, penting dilakukan komunikasi yang efektif agar maksud dan pesan yang 
disampaikan dapat diterima sesuai dengan keinginan pengirim berita. Komunikasi yang efektif adalah komunikasi yang dilakukan baik secara langsung atau melalui media dengan tujuan menimbulkan efek tertentu. Komunikasi yang efektif penting bagi pimpinan karena dua alasan. Pertama, komunikasi adalah proses dimana fungsi-fungsi manajemen seperti merencanakan, mengorganisasikan, memimpin dan mengendalikan pelaksanaan. Kedua, komunikasi adalah kegiatan dimana manajer mencurahkan sebagian besar dari waktunya (Sotyandi, 2007).

\section{Penempatan Kerja Karyawan}

Penempatan (placement) pegawai adalah menempatkan calon pegawai yang diterima (lulus seleksi) pada jabatan/ perkerjaan yang membutuhkannya dan sekaligus mendelegasikan authority kepada orang tersebut (Hasibuan, 2006:62). Menurut Siswanto (2003:9) penempatan pegawai adalah suatu proses pemberian tugas dan pekerjaan kepada tenaga kerja yang lulus dalam seleksi sesuai minat, bakat, pendidikan, pengalaman dan prestasi yang dimiliki dengan persyaratan yang dibutuhkan organisasi dan dijalankan secara kontinuitas dan kronologis dengan wewenang dan tanggung jawab sebesar porsi dan komposisi yang telah ditentukan dan diberikan, serta mampu mempertanggungjawabkan segala resiko dan kemungkinan yang terjadi atas tugas dan pekerjaan wewenang dan tanggung jawab tersebut. Sedangkan menurut Davis (2000:225) : "Placement is assignment of new empoyee to a new different job it includes the initial assignment of new employee and the promotion, transfer, or demotion of present employee".

Nawawi (2007) menyatakan : "Pegawai harus ditempatkan dengan posisi dan perannya yang lebih jelas di dalam organisasi kerja, baik pegawai lama maupun pegawai baru yang diperoleh sebagai hasil seleksi“.Sedangkan menurut Marwansyah (2010:59) Penempatan pegawai adalah : "Penugasan atau penugasan kembali pegawai pada suatu pekerjaan atau jabatan baru“. Selanjutnya khusus untuk mengisi jabatan yang kosong dalam memimpin unit kerja dengan mengambil pegawai dari dalam, hendaklah dipertimbangkan dengan senioritas, yang tersirat didalam masa kerja masing-masing pegawai. Tindakan mengabaikan pertimbangan senioritas dapat menimbulkan rasa kecewa, sehingga pegawai menjadi kurang produktif. Disamping itu jika rasa kecewa cukup besar dapat menimbulkan aktivitas negatif secara sembunyi-sembunyi yang dapat merugikan organisasi kerja secara keseluruhan.

Lebih lanjutnya Nawawi (2007) menyatakan bahwa : "Pertimbangan senioritas saja belum cukup, karena akan dapat berakibat buruk pada organisasi kerja, terutama jika pegawai yang bersangkutan ternyata tidak berprestasi karena kemampuannya rendah". Untuk itu senioritas harus disejajarkan dengan prestasi kerja. Dengan kata lain untuk mengisi suatu jabatan yang kosong dengan mengambil pegawai dari dalam hendaknya dipertimbangkan juga prestasi kerjanya, pertimbangan tersebut sangat penting artinya dalam penempatan pegawai untuk efektivitas kerja pegawai. Hasibuan (20065) menyatakan bahwa prestasi adalah : "Suatu hasil kerja yang dicapai seseorang dalam melaksanakan tugas-tugas yang dibebankan kepadanya didasarkan atas kecakapan, pengalaman dan kesungguhan serta waktu". Prestasi kerja pegawai dapat dilihat dari kompetensi yang dimiliki pegawai yang meliputi pengetahuan, keahlian dan sikap/ perilaku. Seseorang akan bekerja secara berdaya guna dan berhasil guna apabila mengetahui dengan jelas posisinya dalam suatau organisasi kerja. Kejelasan itu sangat penting artinya bagi setiap pegawai karena memungkinkan mengetahui peranan dan sumbangan pekerjaan terhadap pencapaian tujuan organisasi kerja secara keseluruhan. 


\section{Kinerja Karyawan}

Landasan yang sesungguhnya dalam suatu organisasi adalah kinerja. Jika tidak ada kinerja maka seluruh bagian organisasi, maka tujuan tidak dapat tercapai. Kinerja perlu dijadikan sebagai bahan evaluasi bagi pemimpin atau manajer. Nawawi (2007) mengatakan bahwa "Kinerja adalah (a) sesuatu yang dicapai, (b) prestasi yang diperlihatkan, (c) kemampuan kerja". Definisi lain mengenai kinerja menurut Nawawi (2007:63) adalah "Kinerja dikatakan tinggi apabila suatu target kerja dapat diselesaikan pada waktu yang tepat atau tidak melampui batas waktu yang disediakan". Kinerja menjadi rendah jika diselesaikan melampui batas waktu yang disediakan atau sama sekali tidak terselesaikan. Menurut Simamora (2006:7) "Kinerja karyawan adalah tingkat dimana para karyawan mencapai persyaratan-persyaratan pekerjaan".

Hasibuan (2006) menjelaskan bahwa "Kinerja merupakan hasil kerja yang dicapai seseorang dalam melaksanakan tugas-tugas yang dibebankan kepadanya didasarkan atas kecakapan, pengalaman, kesungguhan serta waktu". Prawirosentono (2008)mengatakan bahwa "Kinerja atau dalam bahasa inggris adalah performance", yaitu: Hasil kerja yang dapat dicapai oleh seseorang atau sekelompok orang dalam organisasi, sesuai dengan wewenang dan tanggung jawab masing-masing dalam rangka upaya mencapai tujuan organisasi bersangkutan secara legal, tidak melanggar hukum dan sesuai dengan moral maupun etika.

Mangkunegara (2006) mengatakan bahwa kinerja adalah hasil kerja secara kualitas dan kuantitas yang dicapai oleh seseorang pegawai dalam melaksanakan tugasnya sesuai dengan tanggung jawab yang diberikan kepadanya. Kinerja yang baik adalah kinerja yang mengikuti tata cara atau prosedur sesuai standar yang telah ditetapkan, akan tetapi didalam kinerja tersebut harus memiliki beberapa kriteria agar meningkatkan produktifitas sehingga apa yang diharapkan bisa berjalan sesuai apa yang di inginkan.

\section{METODE PENELITIAN}

\section{Identifikasi Variabel}

Identifikasi variabel dimaksudkan untuk mengetahui variabel apa saja yang digunakan dalam penelitian. Dalam penelitian ini, variabel yang akan diteliti adalah variabel komunikasi terhadap kinerja karyawan yang dimoderasi oleh penempatan kerja karyawan. Adapun variabel-variabel yang akan diteliti :

a. Variabel Bebas (Independent), yaitu variabel yang tidak tergantung pada variabel lain. Dalam penelitian ini yang menjadi variabel bebas adalah komunikasi $\left(\mathrm{X}_{1}\right)$;

b. Moderasi (Moderating), yaitu variabel interaksi antara variabel independen (prediktor) dengan variabel moderator dalam memengaruhi variabel dependen. Dalam penelitian ini yang menjadi variabel moderasi adalah penempatan kerja karyawan $\left(\mathrm{X}_{2}\right)$;

c. Variabel Terikat (Dependent), yaitu variabel terikat dan tergantung pada variabel lain. Dalam hal ini yang merupakan variabel terikat adalah kinerja karyawan (Y).

\section{Definisi Operasional Variabel}

Penelitian ini akan menganalisis tentang pengaruh variabel komunikasi terhadap kinerja karyawan pada KSP Karya Mulya Bondowoso yang diharapkan dapat dimoderasi oleh variabel penempatan kerja karyawan. Variabel-variabel dalam penelitian ini adalah : 
a. Variabel Bebas (X)

Komunikasi $\left(\mathrm{X}_{1}\right)$, yaitu merupakan salah satu kegiatan yang dilakukan untuk mengadakan hubungan dengan karyawannya. Karena itu, penting dilakukan komunikasi yang efektif agar maksud dan pesan yang disampaikan dapat diterima sesuai dengan keinginan pengirim berita.

Indikator :

1) Kepercayaan

2) Pembuatan keputusan bersama

3) Kejujuran

4) Keterbukaan dalam komunikasi

b. Variabel Moderasi $\left(\mathrm{X}_{2}\right)$

Penempatan kerja karyawan $\left(\mathrm{X}_{2}\right)$, yaitu suatu proses pemberian tugas dan pekerjaan kepada tenaga kerja yang lulus dalam seleksi sesuai minat, bakat, pendidikan, pengalaman dan prestasi yang dimiliki dengan persyaratan yang dibutuhkan organisasi dan dijalankan secara kontinuitas dan kronologis dengan wewenang dan tanggung jawab.

Indikator :

1) Kesesuaian bidang pendidikan

2) Pengalaman kerja

3) Pelatihan yang pernah diikuti

4) Beban kerja atau tugas pada tempat yang ditugaskan

c. Variabel Terikat (Y)

Kinerja karyawan adalah hasil kerja yang dicapai seseorang dalam melaksanakan tugas-tugas yang dibebankan kepadanya didasarkan atas kecakapan, pengalaman, kesungguhan serta waktu.

Indikator :

1) Berkualitas dari pekerjaan

2) Ketepatan waktu

3) Inisiatif

4) Kemampuan

5)

\section{Populasi dan Sampel}

Populasi adalah wilayah generasi yang terdiri atas objek/ subjek yang mempunyai kualitas dan kriteria tertentu yang diterapkan oleh peneliti untuk mempelajari dan kemudian ditarik kesimpulannya (Arikunto, 2006). Unit analisis dalam penelitian ini adalah Dinas KSP Karya Mulya Bondowoso. Responden dalam penelitian ini adalah seluruh karyawan tetap yang bekerja di Dinas KSP Karya Mulya Bondowoso yaitu sebanyak 40 orang karyawan. Arikunto (2006) yang menyatakan bahwa sampel adalah sebagian atau wakil dari populasi yang diteliti. Apabila subyek populasi yang kurang dari 100 lebih baik diambil seluruhnya, sedangkan jika subyek lebih dari 100 maka diambil $10 \%$ sampai $15 \%$ atau $20 \%$ sampai $25 \%$ dari populasi. Populasi didalam penelitian ini diketahui jumlah karyawan yang ada tidak melebihi 100 karyawan, maka 40 orang karyawan didalam penelitian ini ditetapkan sebagai responden, atau penelitian ini menggunakan metode sensus. 


\section{Uji Validitas dan Uji Reliabiltas}

Uji validitas bertujuan untuk mengetahui sejauh mana validitas data yang diperoleh dari penyebaran kuisioner. Uji validitas sebagai alat ukur dalam penelitian ini, yaitu menggunakan korelasi product moment pearson's, yaitu dengan cara mengkorelasikan tiap pertanyaan dengan skor total, kemudian hasil korelasi tersebut dibandingkan dengan angka kritis taraf signifikan 5\%, dengan mengunakan rumus, (Prayitno, 2010). Uji reliabilitas digunakan untuk menguji kemampuan suatu hasil pengukuran relatif konsisten apabila pengukurannya diulangi dua kali atau lebih (Prayitno, 2010:75). Reliabilitas berkonsentrasi pada masalah akurasi pengukuran dan hasilnya. Dengan kata lain reliabilitas menunjukkan seberapa besar pengukuran kendali terhadap subjek yang sama. Pengujian kendala alat ukur dalam alat penelitian menggunakan reliabilitas metode alpha $(\alpha)$ yang digunakan adalah metode Cronbach yakni (Prayitno, 2010).

\section{Analisis Deskriptif Statistik}

Analisis deskriptif statistik adalah menggambarkan tentang rinkasan data-data penelitian seperti mean, standar deviasi, varian, modus, dll. Analisis deskriptif ini dapat digunakan untuk memberikan penjelasan dalam penelitian lanjutan untuk memberikan hasil yang lebih baik tehadap analisis regresi. Analisis deskriptif bersifat penjelasan statistik dengan memberikan gambaran data tentang jumlah data, minimum, maxsimum, mean, dan standar deviasi (Prayitno, 2010).

\section{Moderated Regression Analysis (MRA)}

Analisis moderasi menunjukkan interaksi antara variabel independen (prediktor) dengan variabel moderator dalam memengaruhi variabel dependen (Latan, 2013). Pengujian efek moderasi dalam regresi linear dapat dilakukan secara bertahap dengan menggunakan pendekatan yang telah dikembangkan, tiga langkah dalam pengujian efek moderasi ;

a. Langkah pertama, menguji efek utama X ke Y (Pengaruh variabel independen terhadap dependen) dan harus signifikan pada $\mathrm{p}<0,05$;

b. Langkah kedua, menguji variabel $\mathrm{M}$ ke $\mathrm{Y}$ (Pengaruh variabel moderasi ke variabel dependen) dan harus signifikan pada $\mathrm{p}<0,05$;

c. Langkah ketiga, menguji variabel interaksi (Perkalian antara variabel independen dan moderator) terhadap dependen dan harus signifikan pada $\mathrm{p}<0,05$.

Seperti diketahui bahwa Moderated Regression Analysis (MRA) merupakan cara umum yang digunakan untuk menguji efek moderasi, dimana dalam persamaan regresi linearnya mengandung unsur interaksi (perkalian dua variabel antara variabel independen dan variabel moderator). Untuk mengetahui pengaruh komunikasi terhadap kinerja karyawan KSP Karya Mulya Bondowoso yang dimoderasi oleh penempatan kerja karyawan, digunakan analisis regresi linier berganda (Latan, 2013).

Persamaannya dapat ditulis sebagai berikut ;

Pengujian Efek Utama ;

Pengujian Efek Moderasi ;

$$
Y=a+b_{1} X_{1}+e
$$

$$
Y=a+b_{1} X_{1}+b_{2} X_{2}+b_{3} X_{1} * X_{2}+e
$$




\section{Koefisien Determinasi}

Koefisien determinasi adalah data untuk mengetahui seberapa besar prosentase pengaruh langsung variabel bebas yang semakin dekat hubungannya dengan variabel terikat atau dapat dikatakan bahwa penggunaan model tersebut bisa dibenarkan. Dari koefisiensi determinasi $\left(\mathrm{R}^{2}\right)$ dapat diperoleh suatu nilai untuk mengukur besarnya sumbangan dari beberapa variabel X terhadap variasi naik turunnya variabel Y (Prayitno, 2010).

\section{HASIL DAN PEMBAHASAN}

\section{Hasil Statistik Deskripsi}

\section{Karakteristik Responden Berdasarkan Usia}

Usia responden terbagi dalam 3 kelompok dari 40 responden, yaitu 25 - 35 tahun, 36 - 45 tahun, dan diatas 45 tahun. Berdasarkan perhitungan statistic maka karyawan KSP Karya Mulya Bondowoso adalah responden yang berumur diantara 25 - 35 tahun, sedangkan minoritas responden yang menjadi karyawan KSP Karya Mulya Bondowoso adalah responden yang berumur diantara 36 - 45 tahun dan diatas 45 tahun.

\section{Karakteristik Responden Berdasarkan Jenis Kelamin}

Jenis kelamin responden terbagi dalam 2 kelompok dari 40 responden, yaitu lakilaki dan perempuan. Berdasarkan hasil perhitungan dapat diketahui bahwa responden yang paling banyak atau mayoritas yang menjadi karyawan KSP Karya Mulya Bondowoso adalah responden yang berjenis kelamin laki-laki, dan minoritas responden yang menjadi karyawan KSP Karya Mulya Bondowoso adalah responden yang berjenis kelamin perempuan.

\section{Karakteristik Responden Berdasarkan Masa Kerja}

Masa kerja responden terbagi dalam 3 kelompok dari 40 responden, yaitu $<1$ tahun, $1-2$ tahun, $3-4$ tahun dan $>4$ tahun. Berdasarkan hasil perhitungan dapat diketahui bahwa responden yang paling banyak atau mayoritas responden yang menjadi karyawan KSP Karya Mulya Bondowoso adalah responden telah bekerja diantara 3 - 4 tahun, sedangkan minoritas responden yang menjadi karyawan KSP Karya Mulya Bondowoso adalah responden telah lama berkerja selama kurang dari 1 tahun, diantara 1 -2 tahun dan lebih dari 4 tahun.

\section{Karakteristik Responden Berdasarkan Pendidikan}

Pendidikan responden terbagi dalam 3 kelompok dari 40 responden, yaitu, SMA, Diploma, dan Strata 1. Berdasarkan hasil perhitungan dapat diketahui bahwa responden yang paling banyak atau mayoritas responden yang menjadi karyawan KSP Mulya Bondowoso adalah responden telah berpendidikan SMA, sedangkan minoritas responden yang menjadi karyawan KSP Mulya Bondowoso adalah responden telah berpendidikan Diploma dan Strata 1. 


\section{Uji Validitas}

Tabel 1: Hasil Uji Validitas

\begin{tabular}{ccccc}
\hline Indikator & $\begin{array}{c}\text { Product Moment } \\
\text { Pearson's }\end{array}$ & Sig. & $a$ & Keterangan \\
\hline $\mathrm{X}_{1.1}$ & 0,736 & $0,000<0,05$ & Valid \\
$\mathrm{X}_{1.2}$ & 0,621 & $0,000<0,05$ & Valid \\
$\mathrm{X}_{1.3}$ & 0,510 & $0,001<0,05$ & Valid \\
$\mathrm{X}_{1.4}$ & 0,642 & $0,000<0,05$ & Valid \\
$\mathrm{X}_{1.5}$ & 0,603 & $0,000<0,05$ & Valid \\
$\mathrm{X}_{2.1}$ & 0,495 & $0,001<0,05$ & Valid \\
$\mathrm{X}_{2.2}$ & 0,654 & $0,000<0,05$ & Valid \\
$\mathrm{X}_{2.3}$ & 0,362 & $0,022<0,05$ & Valid \\
$\mathrm{X}_{2.4}$ & 0,580 & $0,000<0,05$ & Valid \\
$\mathrm{X}_{2.5}$ & 0,329 & $0,038<0,05$ & Valid \\
$\mathrm{Y}_{1}$ & 0,644 & $0,000<$ & $<0,05$ & Valid \\
$\mathrm{Y}_{2}$ & 0,508 & $0,001<0,05$ & Valid \\
$\mathrm{Y}_{3}$ & 0,419 & $0,007<0,05$ & Valid \\
$\mathrm{Y}_{4}$ & 0,508 & $0,001<$ & $<0,05$ & Valid \\
$\mathrm{Y}_{5}$ & 0,456 & $0,003<$ & $<0,05$ & Valid \\
\hline
\end{tabular}

Sumber : Data Diolah.

Pada tabel 1.dapat diketahui bahwa masing-masing indikator (item) dalam variabel yang digunakan mempunyai hasil nilai product moment pearson's dengan signifikasi $0,000-0,038<0,05$, sehingga indikator (item) yang digunakan dalam variabel penelitian ini dapat dinyatakan sesuai atau relevan dan dapat digunakan sebagai item dalam pengumpulan data.

\section{Uji Reliabilitas}

Pengujian ini dilakukan untuk menunjukkan sejauh mana suatu hasil pengukuran relatif konsisten. Suatu pertanyaan atau peryataan yang baik adalah pertanyaan atau peryataan yang jelas mudah dipahami dan memiliki interpretasi yang sama meskipun disampaikan kepada responden yang berbeda dan waktu yang berlainan. Uji reliabilitas menggunakan cronbach's alpha. Suatu instrument dikatakan reliabel apabila cronbach's alpha lebih besar dari 0,60 (Prayitno, 2010:97). Berikut pada Tabel 4.6 disajikan hasil pengujian reliabilitas ;

Tabel 2. Hasil Uji Reliabilitas

\begin{tabular}{ccccc}
\hline Variabel & Cronbach's Alpha & Cutt off & N of Item & Keterangan \\
\hline $\mathrm{X}_{1}$ & 0,706 & $>0,6$ & 5 & Reliabel \\
$\mathrm{X}_{2}$ & 0,675 & $>0,6$ & 5 & Reliabel \\
$\mathrm{Y}$ & 0,688 & $>0,6$ & 5 & Reliabel \\
\hline
\end{tabular}

Sumber : Data Diolah. 
Berdasarkan tabel 2. terlihat hasil uji reliabilitas diatas menunjukkan bahwa data yang diperoleh bersifat reliabel karena nilai Cronbach's Alpha yakni 0,706, 0,675, dan $0,688>0,60$, sehingga data yang diperoleh dapat dinyatakan reliabel atau layak sebagai alat dalam pengumpulan data.

\section{Analisis Deskriptif Statistik}

Analisis deskriptif statistik adalah menggambarkan tentang rinkasan data-data penelitian seperti mean, standar deviasi, varian, modus, dll. Analisis deskriptif ini dapat digunakan untuk memberikan penjelasan dalam penelitian lanjutan untuk memberikan hasil yang lebih baik tehadap analisis regresi. Analisis deskriptif bersifat penjelasan statistik dengan memberikan gambaran data tentang jumlah data, minimum, maxsimum, mean, dan standar deviasi (Prayitno, 2010:12). Adapun hasil uji Analisis Deskriptif Statistik ;

Tabel 3. Hasil Analisis Deskriptif Statistik

\begin{tabular}{|c|c|c|c|c|c|c|c|}
\hline & Keterangan & $\mathrm{N}$ & & Minimum & Maximum & Mean & Std. Deviation \\
\hline & Komunikasi $\left(\mathrm{X}_{1}\right)$ & 0 & 4 & 3,4 & 4,6 & 4,02 & 0,32 \\
\hline$\left(\mathrm{X}_{2}\right)$ & Penempatan kerja & 0 & 4 & 3,6 & 4,6 & 4,01 & 0,25 \\
\hline$(\mathrm{Y})$ & Kinerja karyawan & 0 & 4 & 3,6 & 4,6 & 4,05 & 0,27 \\
\hline & Valid N (listwise) & 0 & & & & & \\
\hline
\end{tabular}

Sumber : Data Diolah.

Berdasarkan tabel 3, berkaitan dengan analisis deskriptif statistik dapat dilihat bahwa dengan jumlah data sebanyak 40, variabel kinerja karyawan (Y) mempunyai ratarata sebesar 4,05, dengan nilai minimal 3,6 dan maksimal 4,6, sedangkan standar devisiasinya sebesar $0,27 \%$. Variabel komunikasi $\left(\mathrm{X}_{1}\right)$ mempunyai rata-rata 4,02, dengan nilai minimal 3,4 dan maksimal 4,6, sedangkan standar devisiasinya sebesar $0,32 \%$. Variabel penempatan kerja $\left(\mathrm{X}_{2}\right)$ mempunyai rata-rata sebesar 4,01 , dengan nilai minimal 3,6 dan maksimal 4,6, sedangkan standar devisiasinya sebesar $0,25 \%$.

\section{Analisis Regresi Linear Sederhana dan Moderated Regression Analysis}

Analisis efek moderasi berkaitan interaksi antara variabel independen (prediktor) dengan variabel moderator dalam memengaruhi variabel dependen. Pertama adalah menguji efek utama dengan menggunakan regresi linear sederhana. Kedua adalah menguji efek moderasi dengan menggunakan moderated regression analysis (MRA). Hasil analisis efek utama antara variabel independent yaitu komunikasi dan variabel dependen yaitu kinerja karyawan. Hasil analisis efek moderasi antara variabel independen yaitu komunikasi, variabel moderator yaitu penempatan kerja, serta variabel dependen yaitu kinerja karyawan. Berikut pada tabel 4. disajikan hasil analisis efek utama. 
Tabel 4. Hasil Analisis Efek Utama

\begin{tabular}{rccccccc}
\hline Variabel & Unstandardizea & $T$ & & Sig. & $a$ & Keterangan \\
\cline { 2 - 4 } Coefficients B & & & tabel & & & \\
\hline Komunikasi $\left(X_{1}\right)$ & 0,574 & 5,675 &, 024 & 0,000 & 0,05 & Signifikan \\
\hline
\end{tabular}

$R$ Square $=0,574$

Sumber : Data Diolah. adalah ;

Berdasarkan koefisien regresi, maka persamaan regresi yang dapat dibentuk

$$
\mathrm{Y}=1,740+0,574 \mathrm{X}_{1}
$$

a. Nilai konstanta 1,740, menunjukkan bahwa jika tidak ada aktivitas pada komunikasi maka nilai kinerja karyawan sebesar 1,740 ;

b. Nilai koefisien 0,574 pada komunikasi, menunjukkan bahwa setiap kenaikan kegiatan komunikasi 1 satuan, maka hal tersebut akan meningkatkan kinerja karyawan sebesar 0,574, dan sebaliknya.

Tabel 4. Hasil Analisis Efek Moderasi

\begin{tabular}{|c|c|c|c|c|c|c|}
\hline Variabel & $\frac{\text { Unstandardized }}{\text { Coefficients B }}$ & $\mathrm{T}$ & tabel & Sig. & $a$ & Keterangan \\
\hline Constant & 0,888 & & & & & \\
\hline Komunikasi $\left(\mathrm{X}_{1}\right)$ & 0,506 & 4,857 & ,028 & 0,000 & 0,05 & Signifikan \\
\hline $\begin{array}{l}\text { Penempatan kerja } \\
\left(\mathrm{X}_{2}\right)\end{array}$ & 0,284 & 2,147 & ,028 & 0,039 & 0,05 & Signifikan \\
\hline Interaksi $1\left(\mathrm{X}_{1} \mathrm{X}_{2}\right)$ & 0,249 & 2,079 & , 028 & 0,045 & 0,05 & Signifikan \\
\hline \multicolumn{3}{|c|}{ Adjusted $R$ Square $=0,487$} & \multicolumn{4}{|c|}{$\begin{array}{l}F=13,328 \\
\text { Sig }=0,000\end{array}$} \\
\hline
\end{tabular}

Sumber : Data Diolah.

Berdasarkan koefisien regresi, maka persamaan regresi yang dapat dibentuk adalah : $\mathrm{Y}=0,888+0,506 \mathrm{X}_{1}+0,284 \mathrm{X}_{2}+0,249 \mathrm{X}_{1} \mathrm{X}_{2}$

\section{Uji t Analisis Efek Moderasi}

Pengujian ini dilakukan untuk mengetahui apakah variabel independen dan moderated berpengaruh terhadap variabel dependen secara signifikan secara parsial. Tabel distribusi t dicari pada $\alpha=5 \%$ (uji 2 sisi, $0,05: 2=0,025$ ), dengan derajat kebebasan (df) n-k-1 atau 40-3-1 = 46. Hasil analisis moderated regression analysis (MRA) adalah untuk mengetahui pengaruh komunikasi, penempatan kerja serta interaksi 1 terhadap variabel dependen yaitu kinerja karyawan. 


\section{Koefisien Determinasi Analisis Efek Utama}

Berfungsi untuk mengetahui besarnya proporsi atau sumbangan pengaruh variabel independen terhadap variabel dependen secara keseluruhan, maka dapat ditentukan dengan uji koefisien determinasi berganda (R). Hasil analisis menunjukkan bahwa besarnya persentase sumbangan pengaruh variabel komunikasi terhadap kinerja karyawan KSP Karya Mulya Bondowoso, dapat dilihat dari nilai $R$ Square (R) menunjukkan sebesar 0,444 atau 44,4\% dan sisanya 55,6\% dipengaruhi atau dijelaskan oleh faktor-faktor lain yang tidak dimasukkan dalam model penelitian ini, seperti disiplin kerja dan kepuasan kerja karyawan.

\section{Koefisien Determinasi Analisis Efek Moderasi}

Berfungsi untuk mengetahui besarnya proporsi atau sumbangan pengaruh variabel independen, yaitu komunikasi dan penempatan kerja serta variabel moderated yaitu interaksi 1 terhadap variabel dependen secara keseluruhan, maka dapat ditentukan dengan uji koefisien determinasi berganda $\left(\mathrm{R}^{2}\right)$. Hasil analisis menunjukkan bahwa besarnya persentase sumbangan pengaruh variabel komunikasi dengan penempatan kerja sebagai variabel pemoderasi terhadap kinerja karyawan KSP Karya Mulya Bondowoso, dapat dilihat dari nilai Adjusted $R$ Square $\left(\mathrm{R}^{2}\right)$ menunjukkan sebesar 0,487 atau $48,7 \%$ dan sisanya $51,3 \%$ dipengaruhi atau dijelaskan oleh faktor-faktor lain yang tidak dimasukkan dalam model penelitian ini, seperti kepuasan kerja karyawan, kompensasi, serta bonus kerja.

\section{Pembahasan}

Hasil pengujian koefisien dari analisis efek utama menunjukkan bahwa komunikasi berpengaruh terhadap kinerja karyawan KSP Karya Mulya Bondowoso, dan pengujian koefisien dari analisis efek moderasi menunjukkan bahwa komunikasi dengan penempatan kerja sebagai variabel pemoderasi terhadap kinerja karyawan KSP Karya Mulya Bondowoso. Hasil pengujian koefisien dari analisis efek utama, menunjukkan bahwa komunikasi berpengaruh signifikan terhadap kinerja karyawan KSP Karya Mulya Bondowoso dengan arah positif. Hasil pengujian koefisien dari analisis efek moderasi, menunjukkan bahwa interaksi antara komunikasi dan penempatan kerja sebagai variabel pemoderasi terhadap kinerja karyawan KSP Karya Mulya Bondowoso. Berdasarkan hasil pengujian tersebut, maka dapat disimpulkan bahwa hipotesis yang menyatakan, "ada pengaruh komunikasi terhadap kinerja karyawan KSP Karya Mulya Bondowoso" dan "ada interaksi antara komunikasi dan penempatan kerja sebagai variabel pemoderasi terhadap kinerja karyawan KSP Karya Mulya Bondowoso" adalah diterima.

\section{Pengaruh Komunikasi Terhadap Kinerja Karyawan}

Penelitian yang dilakukan, menunjukkan bahwa nilai koefisien variabel komunikasi sebesar 0,574 atau 57,4\% dengan arah positif. Komunikasi sebagai proses dimana suatu ide dialihkan dari sumber kepada satu penerima atau lebih, dengan maksud untuk mengubah tingkah laku mereka dan merupakan faktor penentu tersampaikannya informasi adalah baik, dengan artian lainnya bahwa adanya komunikasi dan informasi yang diberikan didasarkan atas dasar dan dibangun berdasarkan prinsip kepercayaan diantara karyawannya, adanya komunikasi yang baik diantara karyawan yang dapat memberikan keputusan yang jelas didalam mencari solusi didalam permasalahan kerja karyawannya, adanya kejujuran karyawan didalam memberikan sebuah informasi yang 
pasti dan akan menjadikan suatu perkerjaan dapat dilakukan dengan sesuai dengan informasi yang ada, adanya komunikasi yang ada dibangun dengan keterbukaan diantara karyawannya, telah menjadikan informasi yang diberikan dapat berguna dan sesuai dengan kebutuhan didalam mencari solusi didalam permasalahan kerja sehingga permasalah kerja yang ada akan dapat diselesaikan dengan solusi dan teknis yang baik, serta menjadikan karyawan dapat berkerja dengan waktu yang relatif lebih cepat kebenaran, kejelasan dan kesesuaian informasi yang dibutuhkan akan menentukan hasil yang berkualitas didalam suatu tugas yang telah ditanggungjawabkan kepada karyawannya didalam berkerja.

\section{Pengaruh Penempatan Kerja Sebagai Moderating Antara Komunikasi Terhadap Kinerja Karyawan}

Penelitian yang dilakukan, menunjukkan bahwa nilai koefisien variabel intraksi 1 antara komunikasi dengan penempatan kerja sebagai moderating terhadap kepuasan kerja sebesar 0,249 atau 24,9\% dengan arah positif. Penempatan kerja sebagai suatu proses pemberian tugas dan pekerjaan kepada tenaga kerja yang lulus dalam seleksi sesuai minat, bakat, pendidikan, pengalaman dan prestasi yang dimiliki dengan persyaratan yang dibutuhkan organisasi dan dijalankan secara kontinuitas dan kronologis dengan wewenang dan tanggung jawab yang telah diberikan organisasi kepada seorang karyawannya adalah baik, dengan artian lain bahwa adanya komunikasi yang diberikan sesuai dengan prinsip kepercayaan didalam organisasi, tentunya akan menjadikan karyawan dapat berkerja secara baik dan merasa sesuai dengan bidang kerja atau tugas yang telah diberikan pimpinan organisasi didalam mengurusi suatu permasalahan kerja sehingga permasalahan kerja yang ada yang didukung dengan pemberian informasi yang jelas dan terpercaya akan menciptakan adanya pelaksanaan tugas yang sesuai dengan prosedur kerja yang telah direncanakan dan ditetapkan didalam organisasi; adanya komunikasi yang terjaga dengan baik dan hubungan yang baik diantara karyawannya akan menjadikan karyawan mampu didalam mengefektifkan pelaksanaan kerja pada bidang dan bagian tugasnya didalam organisasi sehingga bidang kerja atau bagian kerja yang telah memberikan pengalaman dan keahlian didalam berkerja akan semakin memudahkan informasi yang diterima untuk diproses secara teknis dalam proses kerja yang ada; adanya karyawan yang berlaku jujur didalam berkerja, tentunya akan sangat dibutuhkan dalam proses komunikasi sebagai penyampaian informasi didalam suatu sistem perencanaan dan pelaksanaan kerja sehingga dengan adanya penempatan karyawan yang sesuai dan layak didalam memproses informasi yang akan dijadikan bahan untuk merencanakan dan melaksanakan tugas kerja akan dapat meningkatkan dan mempercepat proses pelaksanaan teknis kerja yang ada didalam suatu organisasi; dan adanya komunikasi yang dibangun dengan keterbukaan diantara karyawannya, tentunya akan menciptakan adanya efektivitas didalam berkerja, didalam suatu organisasi setiap bagian bidang kerja yang ada akan membutuhkan kejelasan dan keterbukaan informasi yang sesuai sehingga proses administrasi sebagai teknis diantara bagian - bagian yang ada didalam suatu organisasi akan sangat mendukung pencapaian hasil kerja yang sesuai dengan kualitas dan hasil yang ingin dicapai. 


\section{KESIMPULAN DAN SARAN}

Berdasarkan hasil analisis yang telah dilakukan pada penelitian ini, maka dapat ditarik kesimpulan terdapat pengaruh komunikasi terhadap kinerja karyawan KSP Karya Mulya Bondowoso dengan arah positif. Hal ini membuktikan bahwa dengan adanya komunikasi yang efektif didalam penyampaian informasi akan meningkatkan kinerja. Terdapat interaksi antara komunikasi dan penempatan kerja terhadap kinerja karyawan KSP Karya Mulya Bondowoso. Hal ini berarti bahwa penempatan kerja merupakan variabel pemoderasi antara komunikasi terhadap kinerja karyawan, artinya penempatan kerja yang sesuai dengan kemampuan kerja karyawannya akan sangat mendukung efektifitas komunikasi yang dibangun dengan prinsip kepercayaan, kejujuran dan keterbukaan, hal ini tentunya akan memoderasi komunikasi sebagai informasi dalam meningkatkan efektifitas kinerja.

Berdasarkan hasil penelitian dan kesimpulan, maka dapat disarankan sebagai berikut1). Pihak Manajemen KSP Karya Mulya Bondowoso diharapkan dapat lebih mengembangkan komunikasi yang efektif dalam organisasi, diharapkan informasi yang cepat, jelas dan sesuai akan mempercepat proses didalam berkerja; 2).Pihak Manajemen KSP Karya Mulya Bondowoso diharapkan dapat lebih menyesuaikan penempatan kerja karyawan dengan kesesuain bidang pendidikan, pengalaman kerja, pelatihan yang pernah diikuti, beban kerja atau tugas pada tempat yang di tugaskan sehingga akan mendukung proses komunikasi dan informasi yang dibutuhkan didalam proses kerja; 3). Bagi Peneliti dapat mengetahui bahwa teori yang mengatakan adanya pengaruh komunikasi terhadap kinerja dengan penempatan sebagai interaksi itu benar terjadi dalam KSP Karya Mulya Bondowoso; 4). Bagi akademisi dapat menggunakan hasil penelitian ini sebagai acuan bagi peneliti selanjutnya yang topiknya sama dengan penelitian ini.

\section{DAFTAR PUSTAKA}

Arikunto, Suharsimi. 2006. Prosedur Penelitian (Suatu Pendekatan Praktik). Jakarta: PT. Rineka Cipta.

Davis, Keith, \& Jhon W. Newstrom. 2000. Perilaku Dalam Organisasi. Jakarta: Erlangga

Fadilah. 2012. Pengaruh Penempatan Pegawai Terhadap Kinerja Pegawai Pada Sekretariat Daerah Kabupaten Gresik. Jurnal : Administrasi Publik (JAP) Jurusan Administrasi Publik, Fakultas Ilmu Administrasi, Universitas Brawijaya, Malang

Hasibuan, Malayu S.P. 2006. Manajemen Sumber Daya Manusia. Edisi Revisi. Jakarta: Bumi Aksara

Henry Simamora. 2006. Manajemen Sumber Daya Manusia. Yogyakarta: STIE TKPN.

Kiswanto. 2010. Pengaruh Kepemimpinan dan Komunikasi Terhadap Kinerja Karyawan Kaltim Pos Samarinda. Jurnal : EKSIS Riset

Latan, Hengky. 2013. Analisis Multivariat Teknik dan Aplikasi. Bandung : Alfabeta 
Mangkunegara, A.A.Anwar Prabu 2006.Perilaku Dan Budaya Organisasi. Bandung:PT. Refika Aditama.

Marwansyah. 2010. Manajemen Sumber Daya Manusia. Penerbit Bumi Aksara. Jakarta

Nawawi, Hadari. 2007. Manajemen Sumber Daya Manusia untuk bisnis yang kompetitif. Gajah Mada university Press. Yogyakarta

Prabasari. 2011. Pengaruh Disiplin Kerja, Motivasi dan Komunikasi Terhadap Kinerja Karyawan PT PLN Persero Dsitribusi Bali. Jurnal : Fakultas Ekonomi Universitas Udayana (UNUD), Bali, Indonesia

Prawirosentono, Suyadi. 2008. Manajemen Sum berdaya Manusia Kebijakan Kinerja Karyawan. Yogyakarta: BPFE

Prayitno, Duwi. 2010. Paham Analisa Data Statistik. Yogyakarta : MediaKom

Purwanto, R. 2003. Manajemen Sumber Daya Manusia untuk Perusahaan Dari Teknologi ke Praktik. Jakarta: PT. Rajagrafindo Persada.

Purwanto, R. 2008. Manajemen Sumber Daya Manusia untuk Perusahaan Dari Teknologi ke Praktik. Jakarta: PT. Rajagrafindo Persada

Putra. 2010. Pengaruh Penempatan Kerja Karyawan Terhadap Kinerja Pegawai Pada Dinas Perindustrian dan Perdagangan Provinsi Riau. Skripsi : Jurusan Manajemen Fakultas Ekonomi Universitas Islam Riau.

Robbins, Stephen P. 2007. Perilaku Organisasi Edisi kesepuluh. Jakarta: PT Indeks Kelompok Gramedia

Sedarmayanti. 2007. Manajemen Sumber Daya Manusia. Bandung : Refika Aditama.

Siagian S.P. 2005. Organisasi Kepemimpinan dan Perilaku Administrasi. Gunung Agung, Jakarta.

Siswanto Sastrohadiwiryo. 2003. Manajemen Tenaga Kerja Indonesia. Jakarta: PT. Bumi Aksara.

Sotyandi. 2007. Pemahaman Praktis Sumber Daya Manusia. CV. Mandar Maju, Jakarta

Sugiyono. 2008. Metode Penelitian Bisnis. CV. Alfabeta, Bandung.

Sunarto. 2003. Komunikasi Bisnis I. Yogyakarta : Penerbit Amus

Sutrisno, Edy. 2010. Manajemen Sumber Daya Manusia. Jakarta: Kencana

Wursanto. 2005. Perilaku Dan Manajemen Organisasi. Jakarta : Erlangga 